\title{
Biocontrol efficacy of bay essential oil against housefly, Musca domestica (Diptera: Muscidae)
}

\author{
Jyoti M. Chintalchere, Mudasir A. Dar ${ }^{*}$ and Radhakrishna S. Pandit ${ }^{*}$
}

\begin{abstract}
Background: The synanthropic housefly, Musca domestica, augments the transmission of several detrimental diseases like cholera and avian flu. Consequently, during the last century, many physico-chemical methods including synthetic compounds have been applied for its control. But these methods have proven to be prohibitive due to their side effects and serious issues like resistance development, environmental contamination, and detrimental effects on non-target fauna. Therefore, in view of these objectives, we investigated the effects of bay essential oil (EO) against M. domestica.
\end{abstract}

Methods: The attractant/repellent assays were conducted by double choice technique. Different enzyme assays evaluating the effect of $L C_{50}$ concentration of the tested essential oil on larval gut were taken into consideration. To determine the composition, the tested oil was subjected to GC-MS/MS analysis. Further, the morphological alterations caused by EO treatment to third instar larvae were observed in a Nova Nano SEM machine. Data was statistically analyzed by one-way ANOVA using Tukey's test $(p<0.001)$. The $L C_{50}$ and $L C_{90}$ values were calculated by probit analysis.

Results: The adulticidal bioassay revealed significant effects with $\mathrm{LC}_{50}$ concentration as $43.03 \mathrm{mg} / \mathrm{dm}^{3}$ against the newly emerged adult flies while in larvicidal assay mortality was dose dependent showing maximum effect at $\mathrm{LC}_{50}$ $0.0629 \mu \mathrm{g} / \mathrm{cm}^{2}$. The pupicidal activity was more effective at a dose of $L_{50} 64.09 \mu \mathrm{l} / 0.25 \mathrm{~L}$ of air which either killed the pupae or caused deformity in the emerged adults. Likewise total sugar, protein, glycogen, and lipid contents of larvae were reduced after treatment with EO when compared with the normal larvae along with some gut enzymes. The EO reduced the acetylcholinesterase activity from $0.013 \mathrm{U} / \mathrm{mg}$ protein in normal larvae to $0.0093 \mathrm{U} / \mathrm{mg}$ protein after EO treatment. The GC-MS/MS analysis of the bay EO showed the abundance of myrcene, linalool, eugenol, chavicol, and anethole along with diterpenoid, geranylgeraniol. However, the insecticidal activity of tested EO might be majorly imparted by eugenol content. The FESEM analysis showed shrinkage of integument and distortion to intersegmental regions caused by the tested compound.

Conclusion: The present study concludes the significant efficacy of bay EO against M. domestica which could be employed to breakdown its population below threshold levels to prevent the menace of vector-borne diseases.

Keywords: Biocontrol, Essential oil, Laurus nobilis, Musca domestica, FESEM, GC-MS

\footnotetext{
*Correspondence: mudasir.dar@unipune.ac.in; panditrao499@gmail.com Department of Zoology, Savitribai Phule Pune University, Pune, Maharashtra 411007, India
} 


\section{Background}

The housefly, Musca domestica (Diptera: Muscidae), is a well-known pest of livestock and human health importance. It constitutes a worldwide problem wherever poor sanitation and bad hygienic conditions exist (Khan et al., 2013). Moreover, the biology and ecology of Musca domestica makes it an ideal organism to carry and disseminate human and animal pathogens, such as helminth parasites, protozoan cysts, viruses, and bacteria (Fotedar et al., 1992; Greenberg, 1973; Kobayashi et al., 1999). Recently, it has been inculpated to transmit avian flu (Wanaratana et al., 2013) also. Therefore, hitherto, a large variety of synthetic compounds such as DDT and cyromazine have been used against this vector to prevent the epidemics. However, indiscriminate use of these chemical insecticides has resulted in many serious problems like insect resistance, persistence of chemicals in the environment, and biomagnifications through trophic levels leading to detrimental effects on human beings (Tabashnik \& Johnson, 1999). Therefore, researchers are continuously prospecting for active natural products of plant origin as potential alternatives to conventional insecticides.

The eco-toxicological property of plants such as lower toxicity to humans, cheap, easy cultivation and degradation along with reduced environmental impact makes them promising candidates for the management of insect pests (Kumar et al., 2011). Additionally, aromatic plants have proved effective insecticides and their essential oils (EOs) often constitute the bioactive fraction (Regnault-Roger, 1997). Plant metabolites act by either exerting their effect on octopaminergic nervous system of insect pests (El-Zayyat et al., 2017) or interfering with GABA-gated chloride channels (Khater, 2012). Further effects can be seen in behavioral modifications (attraction/repellency) and contact toxicity for different life stages of the targeted organisms. Similarly, some natural oils are complexes of many biologically active constituents including terpenes, acyclic monoterpene alcohols, monocyclic alcohols, aliphatic aldehydes, aromatic phenols, monocyclic ketones, bicyclic monoterpenic ketones, acids, and esters (Koul, 2008).

In the past few years, there is a strong impetus to develop EOs of botanical origin as potential agents for pest control strategies. Since aromatic angiosperm, Laurus nobilis L., is widely exploited for treatment of gastrointestinal disorders (Lorenzi \& Matos, 2008), the aqueous extracts of this plant are also used for the treatment of many open wounds from ancient times (Nayak et al., 2006). In view of these properties, the present study aimed to determine the chemical composition of Laural nobilis essential oil and evaluate its efficiency against Musca domestica. Further, we investigated the larvicidal effect and oviposition deterrent activities posed by this oil to the different life stages of the fly.

\section{Materials and methodology}

\section{Chemicals and reagents}

The EO of the Laurus nobilis was supplied by Sigma Aldrich, USA. The oil doses were prepared freshly by dilution in acetone solvent and immediately used for tests. All other chemicals/reagents used in this study were of highest purity and molecular or analytical grade unless defined.

\section{Rearing of housefly colony}

The laboratory-reared colonies of the model organism, i.e., $M$. domestica, were generously provided by the Entomology Section, National Chemical Laboratory (NCL), Pune (M.S.), India, which were free from insecticides and pathogens. The culture of housefly was maintained in vitro at a temperature of $28 \pm 2{ }^{\circ} \mathrm{C}$ and $60-70 \%$ relative humidity $(\mathrm{RH})$ in plastic jars $(35 \times 15 \mathrm{~cm})$, covered with cheese cloth for several generations. A cotton swab soaked in milk $(10 \% \mathrm{w} / \mathrm{v})$ was offered as a food to adult flies which also served as a substratum for oviposition. The eggs were transferred to another set of jars containing animal feed and water or cotton swab soaked in milk for hatching and larval development. Similarly, pupae were collected and kept in another container for adult emergence. All stages of the fly such as eggs, larvae, pupae, and adults were continuously available for the experiments.

\section{Larvicidal and adulticidal bioassays}

The larvicidal and adulticidal bioassays were carried out by following the methods of Busvine (Busvine, 1971) and Palacios et al. (2009), respectively, with few modifications. To determine the effect of EO, 10 individuals of the third instar larvae were exposed to different concentrations of EO in each test. Primarily, a range of desirable doses were tested to determine the $\mathrm{LC}_{50}$ and $\mathrm{LC}_{90}$ values. For residual film method, $1 \mathrm{ml}$ each of different concentrations of EOs was applied on filter paper discs kept inside the glass petri dish of $90 \mathrm{~mm}$ diameter. The EO doses were applied uniformly in order to make a uniform film over the filter paper. Initially, the treated petri dishes were air dried for few minutes to allow the solvent evaporation, followed by release of larvae $(n=10)$ and then incubating the plates under laboratory conditions for $24 \mathrm{~h}$.

In case of adulticidal assay, 10 adult flies were placed in plastic jars $\left(1.2 \mathrm{dm}^{3}\right)$ containing a $7-\mathrm{cm}$-long cotton yarn suspended from the cap of the jar. Different dosages of EO ranging from 10 to $100 \mathrm{mg} / \mathrm{dm}^{3}$ were used for the tests. Each dose was applied after being dissolved in $10 \mu \mathrm{l}$ of acetone then applied to a cotton yarn. In the control jar, the cotton yarn was treated with $10 \mu \mathrm{l}$ of acetone only. The jars were then sealed tightly and kept at $28 \pm 2{ }^{\circ} \mathrm{C}$ for $30 \mathrm{~min}$. All tests were replicated five 
times with acetone solution being used as a control treatment. The mortality rate of the treated larvae and flies was calculated after $24 \mathrm{~h}$ of treatment by using below mentioned formula 1 . Where $X$ denotes the percentage of larvae that survived in the control test and $Y$ represents the percentage survival of larvae in the tested doses.

$$
\text { Mortality }(\%)=[X-Y / X] 100
$$

The data were pooled and analyzed by standard probit analysis to obtain $\mathrm{LC}_{50}$ and $\mathrm{LC}_{90}$ values. However, the actual dose of EO present in $1 \mathrm{ml}$ mixture was calculated by using the formula 2 .

$$
\text { Dose } / \mathrm{cm}^{2}=\text { value present in } 1 \mathrm{ml} / \text { area of petridish }
$$

\section{Attractant/repellant bioassays}

The attractant and repellant bioassays were carried out by using the double choice method (Campbell, 1983) where 20 newly emerged adults of mixed sexes were released in a cage (size $20 \times 12 \times 8 \mathrm{~cm}$ ) with two conical flasks. One flask contained $0.1 \%$ test oil in $5 \mathrm{ml}$ of milk, while the other contained acetone as a solvent and $5 \mathrm{ml}$ of milk to serve as control. The conical flasks were fitted with funnel $(10 \mathrm{~cm}$ in diameter) to avoid the escape of the flies. The assays were replicated five times, and the numbers of flies attracted towards the tested oil flask and in the control flask were counted after $24 \mathrm{~h}$ to determine the percentage of repellency. The results were expressed in terms of percentage (\%) attraction whereas percentage repellency $(\% R)$ was calculated by the following formula.

$$
\% \mathrm{R}=[100(C-T) / C]
$$

where $C$ is the number of flies trapped in the control flask and $T$ indicates the number of flies trapped in the treated flask.

\section{Pupicidal bioassay}

Pupicidal bioassays were carried out by following the method described by Kumar et al. (Kumar et al., 2011) with slight modifications. The bioassays were performed with 20 pupae ( 3 days old) in a $250-\mathrm{ml}$ conical flask. The pupae were exposed to different doses in the range of $20 \mu \mathrm{l} / 0.25 \mathrm{l}$ to $100 \mu \mathrm{l} / 0.25 \mathrm{l}$ of air to assess the effect of fumigation through impregnation on a cotton swab. In control treatment, the pupae were exposed to acetone only. These pupicidal assays were performed at $28 \pm$ $2{ }^{\circ} \mathrm{C}$ and $\mathrm{RH} 65 \pm 5 \%$. The observation was recorded till the $6^{\text {th }}$ day after exposure to EOs during which emergence into adults was documented. These assays were carried out with five or more independent replicates.
The percent inhibition rate (\% IR) on pupal emergence was calculated by using the below given formula no. 4 .

$$
\text { \%inhibition rate }=\mathrm{Cn}-\mathrm{Tn} / \mathrm{Cn} \times 100
$$

where $\mathrm{Cn}$ represents the number of newly emerged insects in the control set and Tn depicts the number of insects emerged after treatment.

\section{Effect of essential oil on biochemical aspects of housefly larvae}

In larvicidal bioassays, 10 individuals of third instar larvae of the fly were exposed to $\mathrm{LC}_{50}$ concentrations of essential oil for $24 \mathrm{~h}$. After the treatment, the exposed larvae were collected and subjected to biochemical analyses such as determination of total sugars, glycogen, lipids, and proteins by following the Anthrone method specified by Plummer (Plummer, 1988). However, proteins and lipids were estimated by the methods of Bradford (Bradford, 1976) and Van Handel and Day (Van Handel \& Day, 1988), respectively. Results obtained were analyzed with one-way ANOVA, followed by Tukey's test (mean comparison) using GraphPad software version 3.6.

\section{Enzyme assays}

Different enzyme assays were carried out by treating the larvae with $\mathrm{LC}_{50}$ concentration approximately as described in the larvicidal bioassay. The whole guts of the treated larvae were suspended in lysis buffer and homogenized on ice using a glass homogenizer. The homogenate was centrifuged at $10,000 \mathrm{rpm}$ for $10 \mathrm{~min}$ at $4{ }^{\circ} \mathrm{C}$. The supernatant obtained was treated as enzyme extract and used for different enzyme assays. The $\alpha$-amylase activity was determined by dinitrosalicylic acid (DNSA) procedure described by (Bigham et al. 2010), using 1\% $(\mathrm{w} / \mathrm{v})$ starch as substrate. Briefly, $20 \mu \mathrm{l}$ of the enzyme extract was mixed with $50 \mu \mathrm{l}$ of PBS (pH 7.4) and $25 \mu \mathrm{l}$ of $1 \%$ starch solution $(\mathrm{w} / \mathrm{v})$. The mixture was incubated at $35^{\circ} \mathrm{C}$ for $30 \mathrm{~min}$ to allow the reaction to occur which was subsequently terminated by adding $85 \mu \mathrm{l}$ DNSA reagent. The terminated reactions were heated in a boiling water bath for $10 \mathrm{~min}$. Similarly, $\alpha$ - and $\beta$-glucosidase activities were determined by measuring the amount of p-nitrophenol released from $5 \mathrm{mM}$ p-nitrophenyl- $\alpha-\mathrm{D}$ glucopyranoside and $\mathrm{p}$-nitrophenyl- $\beta$-D-glucopyranoside, respectively. Here the assay mixtures were incubated at $25^{\circ} \mathrm{C}$ for $30 \mathrm{~min}$ followed by termination with $100 \mu$ of $\mathrm{NaOH}(0.1 \mathrm{M})$ solution. The absorbance was read spectrophotometrically at $540 \mathrm{~nm}$, and the reducing sugars released were estimated by using glucose as standard. 
Inhibition of acetylcholinesterase (AChE) activity

To determine the acetylcholinesterase (AChE) activity caused by the EO treatment, the sample preparation was carried out as described above except in place of the whole gut only head regions were taken for inhibition analysis. The activity was assayed by the modified method of Ellman and colleagues (Ellman et al., 1961). Briefly, $10 \mu \mathrm{l}$ of enzyme extract was mixed with $10 \mu \mathrm{l}$ deionized water, incubated at room temperature for $15 \mathrm{~min}$ followed by addition of $20 \mathrm{mM}$ acetylthiocholine iodide and $10 \mu \mathrm{l}$ of 0.5 M DTNB [5,5'-dithiobis (2-nitrobenzoic acid)]. The control was treated by taking acetone in place of the enzyme extract. The absorbances were recorded at $412 \mathrm{~nm}$, and enzyme activity was measured in $\mathrm{U} / \mathrm{min} / \mathrm{mg}$ of protein.

\section{Gas chromatography-mass spectrometric (GC-MS) analysis of essential oil}

The chemical composition of tested EO was analyzed by gas chromatography-mass spectrometric (GC-MS) method. The liquid phase used in the chromatographic procedures helps to characterize the oil constituents responsible for the insecticidal property of the oils. For GC-MS, analysis of bay EO was carried out by the method of Peris and Blazquez (Peris \& Blázquez, 2015). The column temperature in the program was $60{ }^{\circ} \mathrm{C}$ during $5 \mathrm{~min}$, with $6{ }^{\circ} \mathrm{C} / \mathrm{min}$ increase up to $180{ }^{\circ} \mathrm{C}$, followed by a $20^{\circ} \mathrm{C} / \mathrm{min}$ increase up to $280^{\circ} \mathrm{C}$, which was maintained for $10 \mathrm{~min}$. The carrier gas used was helium at a flow rate of $1 \mathrm{ml} / \mathrm{min}$ and a split ratio of 1:30. The analysis was performed using a GCMS-TQ8030 apparatus, equipped with RTX 5MS column. Finally, the component identification was elucidated based on the comparison of their relative retention time and mass spectra analysis with those of NIST11 library data (GC-MS system), and available literature.

\section{Field emission scanning electron microscopy (FESEM)}

In order to have a clear and discernible observation of the effects of oil treatment on larval body, 10 larvae of the third instar stage were treated with $\mathrm{LC}_{50}$ concentration of tested EO. The sacrificed (treated) larvae and control larvae were prepared for FESEM visualization by using the protocol of Kumar et al. (Kumar et al., 2011) with few modifications to compare the structural changes caused by the oil treatment. The specimens were primarily fixed in $2.5 \%$ glutaraldehyde $(\mathrm{v} / \mathrm{v})$ in distilled water for $15-17 \mathrm{~h}$. Thereafter, sample specimens were washed with distilled water for $20 \mathrm{~min}$, followed by fixation in $4 \%$ osmium tetroxide for about $2 \mathrm{~h}$. The samples were washed with deionized water for $20 \mathrm{~min}$ and then dehydrated serially with different grades $(30,50,70$, 90 , and $100 \% \mathrm{v} / \mathrm{v}$ ) of alcohol each for $10 \mathrm{~min}$. After dehydration, samples were subjected to critical point drying (CPD) in hexamethylenedisilazane (HMDS). The specimens were mildly coated with gold (100 ̊) followed by observation at a voltage of $5.0 \mathrm{kV}$ in a FEI NOVA Nano SEM (NPEP303, FEI USA).

\section{Statistical analysis}

Data obtained was subjected to statistical analysis. Results were reported as mean \pm standard error means (SEM) of five or more independent replicates which were subjected to one-way ANOVA using Tukey's test $(p<0.001)$. The $\mathrm{LC}_{50}$ and $\mathrm{LC}_{90}$ values with their $95 \%$ confidence limits were determined by probit analysis which helped to analyze the dose-mortality response (Finney, 1952). Analysis of data was carried out in SPSS software version 19 as well as Microsoft Excel (Microsoft office suite, 2013).

\section{Results}

\section{Larvicidal and adulticidal efficacy}

The larvicidal assay carried out by the residual film method showed that $\mathrm{LC}_{50}$ concentration of the bay $\mathrm{EO}$ shows higher larval mortality at $4 \mathrm{mg} / \mathrm{ml}$ with an actual dose $0.0629 \mu \mathrm{g} / \mathrm{cm}^{2}$ which is a very low concentration. The results observed with the larvicidal assay are depicted in Table 1 . However, the $\mathrm{LC}_{90}$ concentration of the EO was observed to be $9.231 \mathrm{mg} / \mathrm{ml}$ with an actual dose of $0.144 \mu \mathrm{g} / \mathrm{cm}^{2}$ (Fig. 1a). As the dose concentration of EO increases, the percent (\%) mortality of the treated larvae also increased. The efficacy of the tested oil was very significant when compared with the control tests indicating short-term exposure of larvae to lethal doses can markedly increase their mortality over time, thereby reducing the number of viable adults, leading to possible significant diminution in overall population of $M$. domestica. The effect of tested doses of the EO on adult insects showed significant mortality (Fig. 1b) varying with the dose range. However, the $\mathrm{LC}_{50}$ and $\mathrm{LC}_{90}$ concentrations for adult mortality by bay EO were found to be $43.03 \mathrm{mg} / \mathrm{dm}^{3}$ and $84.42 \mathrm{mg} / \mathrm{dm}^{3}$, respectively (Table 1).

\section{Attractant/repellant bioassay}

The EOs derived from plants are volatile, natural, and complex organic compounds characterized by a strong odor formed as secondary metabolites. The repellency potential of the EO from $L$. nobilis was evaluated against housefly in glass chambers. In this assay, EO showed $27.58 \%$ repellency at a concentration of $0.1 \%$ (Table 2 ). Among the tested essential oil concentrations, $0.5 \%$ was found to be the most effective with $100 \%$ repellency whereas no repellency was observed on a dose of $0.1 \%$ after $1 \mathrm{~h}$ of continuous observations. The repellency potential of EO doses followed the pattern $0.1 \%>0.5 \%>$ $1.0 \%$. The tested laurel oil elicited a strong and abrupt 
Table 1 Larvicidal and adulticidal activities of bay essential oil on M. domestica

\begin{tabular}{|c|c|c|c|c|c|c|}
\hline \multirow{2}{*}{$\begin{array}{l}\text { Essential } \\
\text { oil }\end{array}$} & \multirow{2}{*}{$\begin{array}{l}\mathrm{LC}_{50}(\mathrm{mg} / \mathrm{ml})^{\#} \\
\left(\mathrm{mg} / \mathrm{dm}^{3}\right)^{\# \#}\end{array}$} & \multicolumn{2}{|c|}{ 95\% confidential limit $\left(L C_{50}\right)$} & \multirow{2}{*}{$\begin{array}{l}\text { Regression } \\
\text { equation }\end{array}$} & \multirow{2}{*}{$\begin{array}{l}\mathrm{LC}_{90}(\mathrm{mg} / \mathrm{ml})^{\#} \\
\left(\mathrm{mg} / \mathrm{dm}^{3}\right)^{\# \#}\end{array}$} & \multirow{2}{*}{$\begin{array}{l}\text { Chi } \\
\text { square }\end{array}$} \\
\hline & & $\overline{\mathrm{LCL}}$ & $\mathrm{UCL}$ & & & \\
\hline Larvicidal & 4 & 3.48 & 4.45 & $y=0.245-0.98 x$ & 9.231 & $4.37^{*}(5)$ \\
\hline Adulticidal & 43.03 & 34.833 & 50.866 & $Y=0.31-1.33 X$ & 84.42 & $8.051^{*}(5)$ \\
\hline
\end{tabular}

Each value represents the mean of five replicates. $\mathrm{LC}_{50}$ and $\mathrm{LC}_{90}$ are lethal concentrations at which $50 \%$ and $90 \%$ population dies, respectively. ${ }^{*}$ Significant at $p<0.001$.

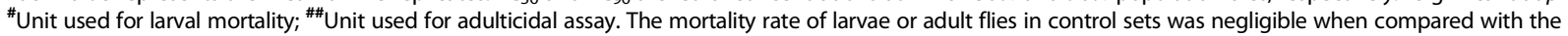
treatment assays

effect against the adults of $M$. domestica at concentrations higher than $0.5 \%$ indicating $0.5 \%$ sufficient for $100 \%$ mortality of the flies.

\section{Pupicidal bioassays}

The pupicidal assay carried out by fumigation and contact toxicity protocols against the tested organism exhibited significant variation in growth inhibition with different doses of the bay EO (Table 2). The results of the fumigation assay revealed that a $\mathrm{LD}_{50}$ dose of bay EO for the pupal death was $64.09 \mu \mathrm{l} / 0.25 \mathrm{l}$ of air (Fig. 2) whereas $\mathrm{LD}_{90}$ concentration was found to be over $104.35 \mu \mathrm{l} / 0.25 \mathrm{l}$ of air. In case of higher doses, a complete inhibition of pupal emergence was noted (Additional file 1: Figure S1). Further, the increase in the dose concentration caused increased percent inhibition rate (PIR) which eventually lead to the deformities in adults in case of survived pupae. Similarly, in contact toxicity, we found that not a single pupa can transform into adult successfully at all tested doses indicating 100\% mortality of the pupae.

\section{Effect of EO on biochemistry of housefly}

The secondary metabolites of the plant origin cause a diverse effect on the metabolism of the insects. Therefore, we tested the effect of different concentrations of the bay EO on the larvae of housefly. The inferences of the present study elucidate that $\mathrm{LC}_{50}$ dose of the bay $\mathrm{EO}$ induced marked reduction in the level of total protein content of the treated larvae as compared with the control set. Further, the biochemical assays revealed that bay EO showed notable changes in total sugar, glycogen, lipid, and protein contents of third instars of $M$. domestica (Table 3). The tested oil remarkably reduced the total sugar content from $3.169 \pm 0.191 \mu \mathrm{g} /$ larva in the control to $0.448 \pm 0.036 \mu \mathrm{g} /$ larva in the treated larva. Not only sugars, the treatment also reduced total glycogen content, i.e., $0.117 \pm 0.007 \mu \mathrm{g} /$ larva after treatment comparable to normal larva $(7.302 \pm 0.131 \mu \mathrm{g} / \mathrm{larva})$. A similar trend was observed with lipid content of the insect where its amount was decreased from 1400.2 \pm $38.87 \mu \mathrm{g} /$ larva in normal individual to $474.62 \pm 57.35 \mu \mathrm{g} /$ larva after treatment. In case of total protein content of the treated and control larvae, the proteins were significantly reduced from $1000.6 \pm 11.47 \mu \mathrm{g} / \mathrm{larva}$ to $636.72 \pm$ $26.98 \mu \mathrm{g} /$ larva due to EO treatment.

\section{Effect of EO on gut enzymes}

Since digestive tract is the main interface between insect and the environment, given that nutrition is a decisive factor in the evolutionary process of these organisms, the main aspect of the pest control is the selective inhibition of digestive enzymes secreted by the alimentary canal of pests. Keeping that in mind, we checked the effect of tested EO on gut enzymes such as $\alpha$-amylase, $\alpha$ and $\beta$-glucosidases. There was a significant difference (Fig. $3 \mathrm{a}-\mathrm{c}$ ) in enzyme activities between treated and control larvae in case of both the enzymes under
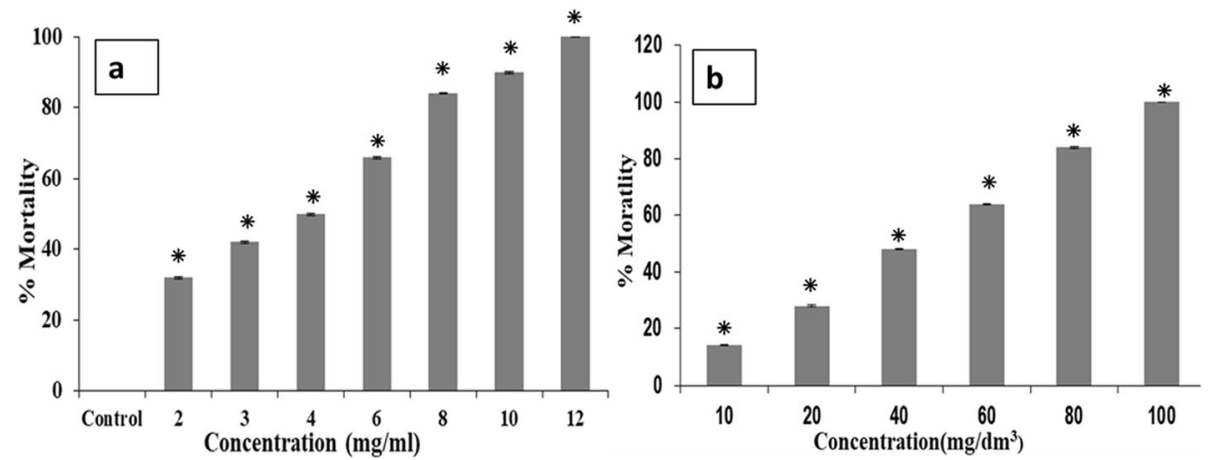

Fig. 1 Bioefficacy of bay essential oil against M. domestica. a Percent mortality of larvae after a treatment of $24 \mathrm{~h}$. $\mathbf{b}$ Adulticidal activity of the tested EO against newly emerged $M$. domestica after $24-\mathrm{h}$ treatment. $L C_{50}$ and $L C_{90}$ are lethal concentrations at which $50 \%$ and $90 \%$ population dies, respectively. Each value represents the mean of five replicates. Asterisk indicates significance at $p<0.05$ 
Table 2 Percent (\%) inhibition repellency of the adult houseflies by different doses of the EO using the fumigation method

\begin{tabular}{|c|c|c|c|c|c|c|c|}
\hline \multirow{2}{*}{$\begin{array}{l}\text { Dose ( } \mu \mathrm{l} / \\
0.25 \text { I of air) }\end{array}$} & \multirow{2}{*}{$\begin{array}{l}\% \\
\text { IR }\end{array}$} & \multirow{2}{*}{$\begin{array}{l}\mathrm{LD}_{50}(\mu \mathrm{l} / \\
0.25 \text { I of air) }\end{array}$} & \multicolumn{2}{|c|}{ 95\% confidential limit $\left(\mathrm{LC}_{50}\right)$} & \multirow{2}{*}{$\begin{array}{l}\text { Regression } \\
\text { equation }\end{array}$} & \multirow{2}{*}{$\begin{array}{l}\mathrm{LD}_{90}(\mu \mathrm{l} / \\
0.25 \text { I of air) }\end{array}$} & \multirow{2}{*}{$\begin{array}{l}\text { Chi } \\
\text { square }\end{array}$} \\
\hline & & & $\mathrm{LCL}$ & UCL & & & \\
\hline 20 & 14 & & & & & & \\
\hline 40 & 22 & & & & & & \\
\hline 60 & 44 & 64.09 & 55.79 & 73.58 & $Y=0.032 x-2.040$ & 104.35 & $9.44^{*}(5)$ \\
\hline 80 & 68 & & & & & & \\
\hline 100 & 88 & & & & & & \\
\hline
\end{tabular}

Each value represents the mean of five replicates. $\mathrm{LC}_{50}$ and $\mathrm{LC}_{90}$ are lethal concentrations at which $50 \%$ and $90 \%$ population dies, respectively. $d f$ degree of freedom. *Significant at $p<0.001$. Negligible repellency or inhibition rate was observed for the control set

consideration showing a $p<0.001$ only. The bay essential oil significantly decreased $\alpha$-amylase activity $(0.092 \pm$ $0.002 \mu \mathrm{g} /$ larva $)$ when compared with control test $(0.214$ $\pm 0.004 \mu \mathrm{g} /$ larva). We observed a substantial decrease of $57.1 \%$ in the activity of $\alpha$-amylase indicating the effect of bay EO on M. domestica. Similarly, the effect of EO on $\alpha$-glucosidase showed considerable reduction (1.878 \pm $0.043 \mu \mathrm{g} /$ larva) in its secretion by fly larvae as compared with control set $(12.375 \pm 0.074 \mu \mathrm{g} /$ larva $)$ marking a difference of $21 \%$. It also showed 1.3 -fold reduction in $\beta$ glucosidase activity from $3.066 \pm 0.071 \mu \mathrm{g}$ /larva to 2.19 $\pm 0.024 \mu \mathrm{g} / \mathrm{larva}$ after treatment with the EO (Additional file 1: Table S1). The tested EO significantly affected the $\alpha$-amylase of the gut extract upon treatment showing a decrease of over $51 \%$ activity (Fig. $3 a$ ).

\section{Acetylcholinesterase (AchE) activity}

As shown in Additional file 1: Figure S2, the bay EO was found to inhibit the AchE activity of $M$. domestica larvae after $24 \mathrm{~h}$ of treatment. The AchE activity in treated larvae was $0.0093 \mathrm{U} / \mathrm{mg}$ of protein compared with control larvae where it was much higher $(0.013 \mathrm{U} / \mathrm{mg}$ of protein) indicating significant reductions caused by the exposure to EO.

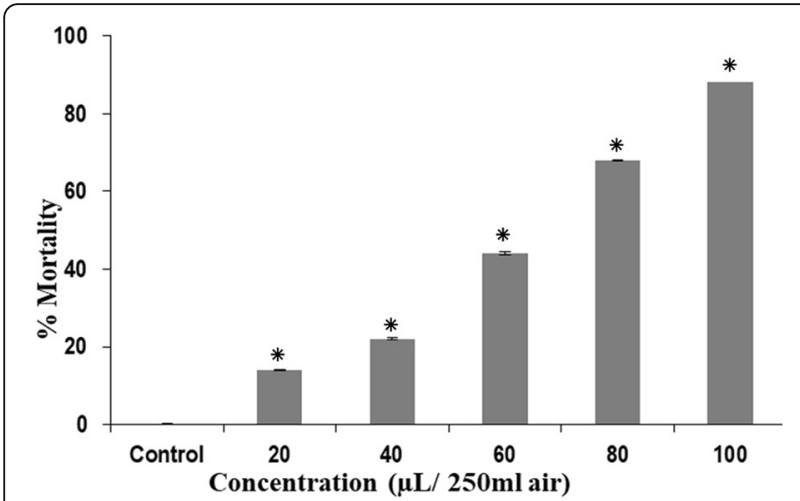

Fig. 2 Pupicidal assay showing percent (\%) mortality of M. domestica larvae by fumigation method with bay EO. Significant ${ }^{*} p<0.001$ when compared with the control. Each value represents the mean of five replicates

\section{GC-MS analysis of essential oil}

The GC-MS analysis of the bay EO revealed an abundance of seven major components (Fig. 4). The components observed (Table 4) were terpenes such as myrcene, linalool (3, 7-dimethyl-1, 6-octadien-3-ol), and diterpenoids (E,E,E)-3,7,11,15-tetramethylhexadeca-1,3,6. Some of the phenolic compounds observed were eugenol, chavicol (phenol,4- (2-propenyl)) and anethole. The highest amount found was of the eugenol (58.95\%) which proved to be the main component followed by phenol (13.96\%), tetra methyl hexadeca (10.57\%), and $\beta$ myrcene (6.03\%). The insecticidal property of this plant EO could be attributed majorly to eugenol content and to some extent linalool compound. However, the compounds like $\beta$-myrcene, eugenol, and linalool comprise only about $3 \%$ of the total chemical compounds present in this plant.

\section{Field emission scanning electron microscopy (FESEM)}

In order to clearly visualize the effect of EO treatment on the larval body surface, we employed FESEM technique to compare the ultra-structural changes in larval integument due to EO treatment with normal larvae. Upon analysis, a clear observation showed the toxic effect of bay oil in the form of integument shrinkage particularly at spinose rings with distorted intersegmental regions. However, control/ normal larvae of $M$. domestica showed normal appearance with a smooth textured integument and well-shaped intersegment spines (Fig. 5a-c). Therefore, it can be concluded

Table 3 Effect of bay EO on nutritional reserves of $M$. domestica larvae

\begin{tabular}{llll}
\hline Sr. no. & Analysis & Control larvae $(\mu \mathrm{g} /$ larva) & Treated larvae $(\mu \mathrm{g} /$ larva) \\
\hline 1 & Sugar & $3.169 \pm 0.191$ & $0.448 \pm 0.036^{*}$ \\
2 & Glycogen & $7.302 \pm 0.131$ & $0.117 \pm 0.007^{*}$ \\
3 & Lipid & $1400.2 \pm 38.87$ & $474.62 \pm 57.35^{*}$ \\
4 & Protein & $1000.6 \pm 11.47$ & $636.72 \pm 26.98^{*}$ \\
\hline
\end{tabular}

Values are mean \pm SE (standard error). Data were analyzed by one-way ANOVA, followed by Tukey's test and significance at ${ }^{*} p<0.001$ compared with the control 


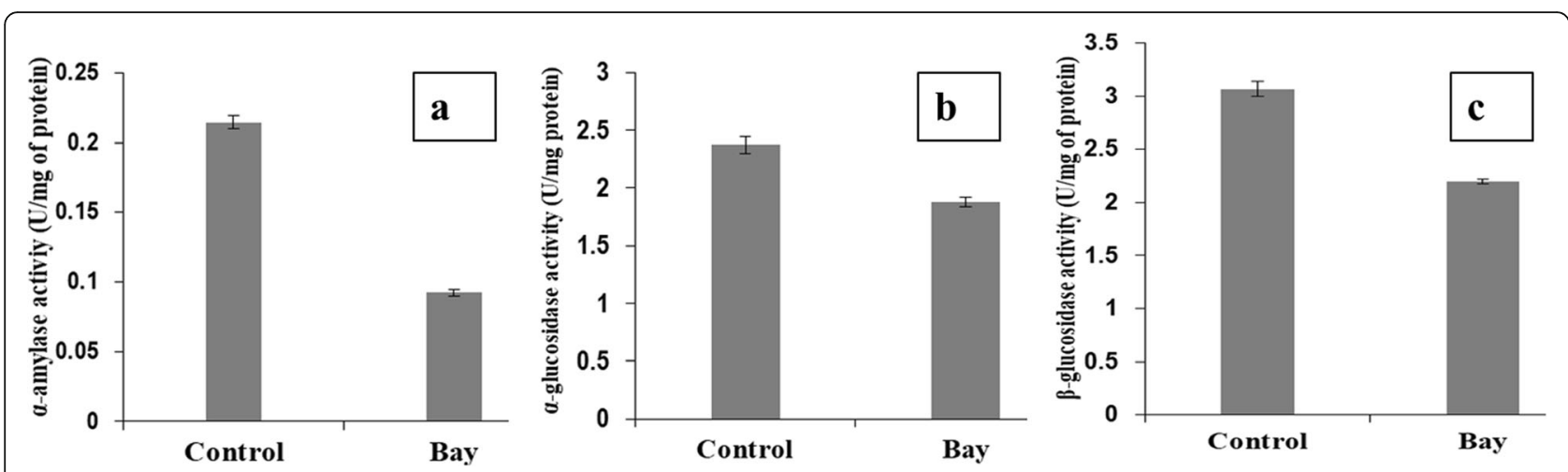

Fig. 3 Effect of bay essential oil on the gut enzymes of $M$. domestica larvae. a a-Amylase, $\mathbf{b}$ a-glucosidase, and $\mathbf{c} \beta$-glucosidase activities of $M$. domestica. Values are means \pm SE (standard error). Data analyzed by one-way ANOVA, followed by Tukey's test and significance at ${ }^{*} p<0.001$ compared with the control

from the observed results that fly larvae upon contact with EO show superficial alterations to the integument.

\section{Discussion}

Pesticides derived from plants are organic in nature, considered to be biodegradable, non-mutagenic or nontoxic to animals, and more particularly target specific than their chemically synthesized counterparts. Some of them also inhibit or reduce the insecticide detoxifying enzymes of the pests thereby could be important from the agriculture viewpoint (Wang et al.,2016). Therefore, keeping in mind the importance of plant-based EOs, we tested the efficacy of EO from $L$. nobilis against the different stages of the nuisance-causing housefly, $M$. domestica. We observed higher larval mortalities at very low doses of the compound which was only $0.0629 \mu \mathrm{g} /$ $\mathrm{cm}^{2}$. The efficacy of Laurus EO against $M$. domestica as observed in this study is much higher than the insecticidal property of EOs derived from various other plants (Pavela, 2008). Recently, the efficiency of the EOs from L. nobilis has been tested on several other insects such as stored grain pests, where authors have suggested species-specific dose requirements for the control of pests (Drapeau et al., 2009; Pavela, 2008; Sertkaya et al., 2010). Ours is the pioneering study to report the effects of $L$. nobilis $\mathrm{EO}$ on the adults of $M$. domestica. Recently, Pavela and his colleagues (Pavela, 2008) tested more than 30 plant extracts against $M$. domestica and concluded that EO from Pogostemon cablin is the most efficient against fly at a concentration of $3 \mu \mathrm{g} / \mathrm{fly}$ which is quite higher than the concentration used in this study. Similarly, Asid and co-workers stated that Citrullus colocynthis extracts exhibit potential efficacy against all stages of $M$. domestica at $50 \%$ concentration (Asid et al., 2015). Previously, many authors have reported the antibacterial (Evrendilek, 2015), antifungal (Gumus et al., 2010), antioxidant (Inan et al., 2012), analgesic and antiinflammatory properties (Sayyah et al., 2003), apart from some acaricidal (Senfi et al., 2014), larvicidal (Pavela, 2008), and insecticidal (Sertkaya et al., 2010) activities by laurel EO.

In order to ascertain the potential of bioactive compounds present in the bay EO, we used the GC-MS analysis that revealed dominance of eugenol and phenolic content which was in congruence with previous reports that have stated the chemical composition of the EO from the leaves of L. nobilis (Senfi et al., 2014; Sertkaya et al., 2010). Further insecticidal property of many compounds present in EO has been conducted topically by Rozman and co-workers (2007) wherein eugenol was found highly toxic to all tested beetles. Eugenol is also known to show higher repellency against beetles (Andronikashvili \& Reichmuth, 2002; Huang et al., 2002; Rozman et al., 2007) and other stored grain pests (Cosimi et al., 2009; Lee et al., 2003). Further, these authors concluded the complete destruction of the eggs and immature stages of $T$. castaneum by eugenol. Our results were in line with Nehir et al. (2014) who found eugenol; 1,8-cineole; linalool; methyl eugenol; $\alpha$-terpinyl acetate; $\alpha$-pinene; and $\beta$-pinene as major components of

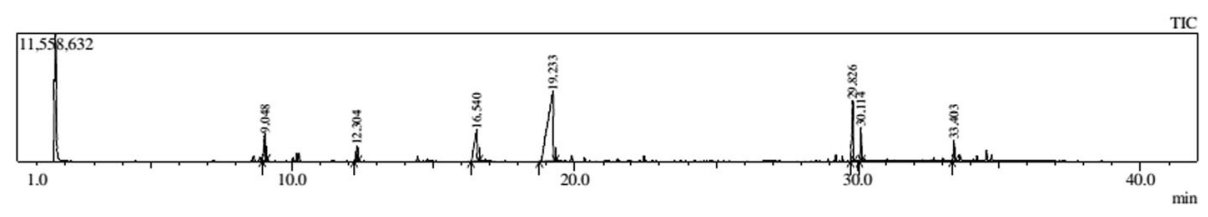

Fig. 4 Chromatogram obtained from GC-MS/MS analysis shows the chemical composition and abundance of some compounds of the bay EO 
Table 4 GC-MS analysis of bay essential oil revealing the abundance of certain compounds

\begin{tabular}{lllllll}
\hline Peak & R. time & Area & Area $\%$ & Height & Height \% & Name \\
\hline 1 & 9.048 & $8,758,593$ & 6.03 & $2,457,962$ & 10.47 & Beta myrcene \\
2 & 12.304 & $5,117,500$ & 3.52 & $1,400,514$ & 5.97 & 1,6 -Octadien-3-ol,3,7-dimethyl \\
3 & 16.540 & $20,281,918$ & 13.96 & $2,876,306$ & 12.26 & Phenol,4-(2-propenyl) \\
4 & 19.233 & $85,635,465$ & 58.95 & $6,319,156$ & 26.93 & Eugenol \\
5 & 29.826 & $15,347,881$ & 10.57 & $5,460,173$ & 23.27 & (E,E,E)-3,7,11,15-Tetramethylhexadeca-1,3,6 \\
6 & 30.114 & $5,874,016$ & 4.04 & $3,065,184$ & 13.06 & (E,E,E)-3,7,11,15-Tetramethylhexadeca-1,3,6 \\
7 & 33.403 & $4,246,485$ & 2.92 & $1,887,660$ & 8.04 & Anethole \\
\hline
\end{tabular}

laurel EO. Most of the terpenoids and phenols of plant origin have minimal vertebrate toxicity and are regarded as safe by United States Food and Drug Administration (USFDA). These compounds apparently cause hyperactivity, tremors, and convulsions followed by knockdown of pests similar to the symptoms by insecticides such as organophosphates and carbamates. However, previously similar signs have been described by insects upon exposure to pure monoterpenes (Coats et al., 1991). Some monoterpenes alter the physiological functions by competitive inhibition of acetylcholine esterase in houseflies and cockroaches (Grundy \& Still, 1985; Ryan \& Byrne, 1988). The toxic effects exerted by EO of $L$. nobilis could be attributed to the toxic constituent like eugenol, linalool, myrcene and other phenolic compounds present therein. Besides the fumigant and repellent activities of bay EO against $M$. domestica, it has also proven insecticidal against red flour beetle, T. castaneum (Cosimi et al., 2009; Lee et al., 2003).

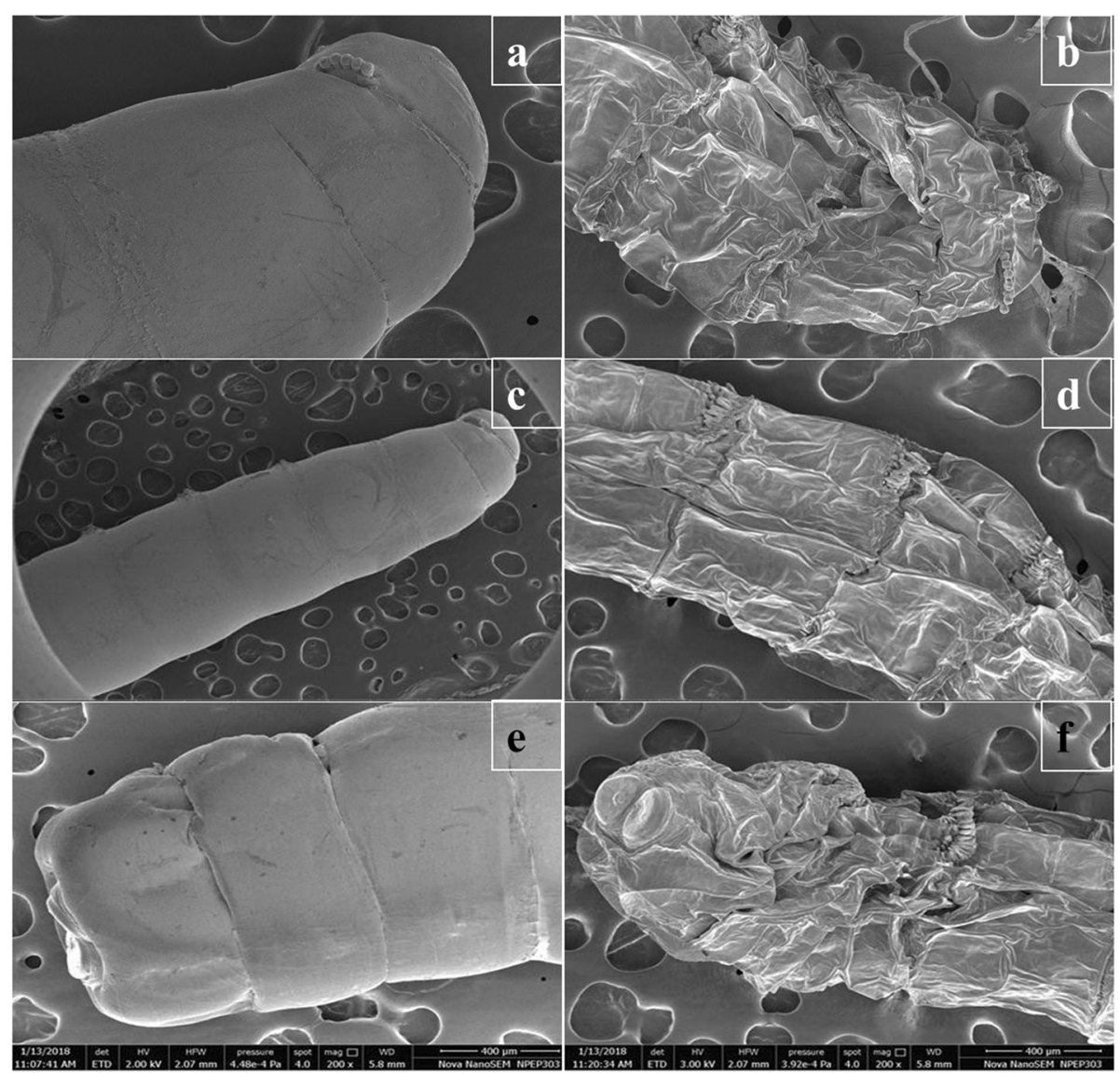

Fig. 5 The ultra-structural and superficial changes induced by bay EO to the larvae of M. domestica after a treatment for $24 \mathrm{~h}$. a, c, and e show the anterior, posterior, and abdominal segments respectively of the control larva exhibiting normal appearance with smooth integument and well-defined or swollen intersegment spines, whereas $\mathbf{b}$, $\mathbf{d}$, and $\mathbf{f}$ show the FESEM micrograph anterior, posterior, and abdominal segments depicting the ultra-structural changes like shrinkage, rupture of body fluids, and corrugation of the integument induced by bay EO during treatment 
Further, monoterpenoids abundantly distributed in EOs of aromatic plants are lipophilic in nature thereby intervene with metabolic, biochemical, physiological, or behavioral functions of insects (Brattsten et al., 1983).

Similar to our study, Palacios et al. (2009b) examined the efficacy of EOs from several medicinal and edible plants against housefly and stated that orange peel and eucalyptus leaves are the most toxic to flies which had limonene (92.5\%) and 1,8-cineole (56.9\%), as the principal compounds. However, Kumar and co-workers (Kumar et al., 2011) have observed that EOs of Mentha piperita and Eucalyptus globules are the most effective plant extracts against $M$. domestica showing both repellent and insecticidal properties. From time immemorial, plant-derived substances have been used to repel or kill mosquitoes before the advent of synthetic chemicals (Curtis et al., 1990). The tested EO also showed higher repellency against adult flies preventing them from oviposition in the nearby vicinity which is also stated by other researchers against rust-red flour beetle Tribolium castaneum (Andronikashvili \& Reichmuth, 2002), Sitophilus zeamais, Cryptolestes ferrugineus, Tenebriomolitor (Cosimi et al., 2009), and adult females of Culex pipiens (Erler et al.2006). The repellency of these compounds appears due to the presence of volatile monoterpenoids (Buescher et al., 1982; Curtis et al., 1990; Rutledge et al.,1983). Besides, Papachristos and Stampoulos (2002) showed that EO from bay plant presented a repellent activity against Acanthoscelides obtectus.

The pupicidal effect exerted by the tested EO was also significant for the bio control of housefly. Besides various fumigant and repellent activities of bay leaf EO against stored grain pest (Cosimi et al., 2009; Lee et al., 2003), there are few reports available about the insecticidal potential of bay leaf oil and its fractions against $T$. castaneum. In the present study, significant mortality or inhibition of pupal emergence was observed by both contact and fumigation pupicidal bioassays. In contrast, Kumar et al. (2011) observed 100\% mortality of the same insect by contact toxicity method only.

Since most insects feed on carbohydrate-rich food products such as seed, fruits, crops, and stored grains, their guts are efficient natural biochemical reactors secreting a suite of hydrolytic enzymes such as amylase and $\alpha$ - and $\beta$-glucosidases. These enzymes hydrolyze $\alpha$ D-1, 4-glucan linkages of starch, glycogen, and some other carbohydrates (Ferreira \& Terra, 1989; Strobl et al., 1998). The amylase enzyme transforms starch into maltose, which is then converted to glucose by $\alpha$ glucosidase and thus utilized as an energy source by the insect. In insects, only $\alpha$-amylases have been found to hydrolyze long $\alpha-1$, 4-glucan chains of starch or glycogen (Terra et al., 1988). Likewise, $\alpha$-glucosidases break non-reducing 1, 4-linked $\alpha$-D-glucose ends of glycogen whereas $\beta$-glucosidases catalyze the hydrolysis of $\beta$ glycosides into respective monosaccharides (Sezginturk \& Dinckaya, 2008). Many insects are known to show $\beta$ glucosidase activities required for metabolism of ingested food such as Diatraea saccharalis (Azevedo et al. 2003) and Parnassiusapollos sp. (Nakonieczny, Michalczyk, \& Kedziorski, 2006). The tested EO depicted neurotoxic effects by inhibiting AchE activity of the $M$. domestica larvae after $24 \mathrm{~h}$ of treatment with $\mathrm{LC}_{50}$ doses only. Many secondary metabolites such as EOs and monoterpenes of aromatic plants are known to inhibit the AchE activity of insects (Senthilm et al., 2008). Our observations were in accordance with Rajashekar and co-workers (2014) who concluded the inhibition of AchE in $M$. domestica by Coumaran, extracted from L. camara. Therefore, for designing a biocontrol strategy, it becomes imperative to understand the interaction of pesticide with digestive enzymes and AchE of the target organism. Hence we determined the effect of EO on gut enzymes of $M$. domestica where drastic changes in expression levels were observed. The treatment with EO reduced the activities of the $\alpha$-amylase and $\alpha$ - and $\beta$-glucosidases by 57.1, 21 , and over $30 \%$, respectively, in treated larvae as compared with larvae without treatment (control).

The reduction in enzyme activity could be a consequence of the cytotoxic effect of plant compounds on epithelial cells of the gut that are responsible for the synthesis of $\alpha$-amylase (Hichri et al.t, 2019). Cytotoxicity appears to include membrane damage by causing coagulation of the cytoplasm (Gustafson et al., 1998) thereby damaging its lipid and protein contents (Ultee et al., 2000) or disrupting cell membrane leading to leakage of macro molecules and ultimately cell lysis (Oussalah et al., 2007). Some plant EOs are also known to form stable complexes with digestive enzymes, making dissociation difficult. In case of biochemical contents, decreased levels of proteins, lipids, and glycogen were observed due to treatment of EO which could be primarily due to blocking of gut hydrolases, which leads to poor nutrient utilization, retarded growth, and consequent death by starvation (Jongsma \& Bolter, 1997). However, the reduction in body protein content may be attributed to inhibition of DNA and RNA synthesis at molecular levels which then reflects the decrease in enzymatic activities. Our results were in congruence with earlier reports (Nathan et al., 2005) where authors have stated similar reduction in protein and metabolite contents in moth, Cnaphalocrocis medinalis, after treatment with plant compounds. The changes in total lipid contents were also caused by the treatment of EOs. Some authors have suggested that decreased lipid content may be a result of transformation of lipids into proteins to substitute the reduction in protein content or produce 
supplementary energy to combat the chemical stress. Hence, treatment with EOs might have interrupted this process and resulted in larval mortality.

The biochemical and metabolic disruption by the EO treatment was also superficially revealed by the FESEM analysis where a complete distortion of the body was observed. Our inferences were supported by the conclusion of Insun et al. (1999) who demonstrated the damage to the surface morphology of mosquito larvae by Kaempferia galangal extract. Moreover, the effect of monoterpenes on insect morphology was also investigated by Sukontason et al. (2004) who studied the structural changes induced in housefly larvae through SEM analysis after the application of eucalyptol oil. The authors reported significant deformation in the integument, inter segmental spines, and bleb formation of the treated larvae. The FESEM analysis of the treated larvae revealed extreme dehydration and surface distortion compared with the undisturbed, free, and smooth surface of control larvae, therefore confiraffirming the effect of tested EO on housefly larvae. The above all results of the presented research indicate that EOs from medicinal plants such as $L$. nobilis could be a potential alternative for use as housefly fumigants, provoking death of the insect within a short period of time.

\section{Conclusions}

The housefly is a cosmopolitan home invader linked to poor hygiene and low socioeconomic status. The search for new, highly selective, biodegradable insecticides is mandatory to solve the problem of residual toxicity to the environment, fauna or flora. Nature provides many products acting as an excellent alternative; among these are the botanical insecticides. With the recent rise of the green insecticide concept and increased public awareness, several attempts to use indigenous plants extracts as potential alternatives have been done, but only few plant-based control products appear in the market. This study recommends the usage of bay-based products in domestic botanical anti-fly insecticides, as it is ethnobotanical, endemic, safe, cheap, and available all year. Therefore, we should overcome barriers in industrialization, commercialization, and creation of market opportunities along with peoples' awareness of its usage.

\section{Supplementary information}

Supplementary information accompanies this paper at https://doi.org/10. 1186/s41936-020-0138-7.

Additional file 1: Figure S1. Histogram depicting percentage inhibition rate (PIR) against housefly pupae in a fumigation toxicity assay by Bay EO. $\mathrm{N}$ : normally emerged adult; DE: deformed pupa/adult; D: dead pupae. Significant ${ }^{*} p<0.001$ when compared to control. Figure S2. Inhibition of Acetylcholinesterase activity by bay EO after $24 \mathrm{hr}$ of treatment. Significance at ${ }^{*} p<0.001$ compared with control). Table S1. Effect of bay EO on the gut/digestive enzymes of the $M$. domestica larvae. Value are mean $\pm \mathrm{SE}$ (Standard error). Data were analyzed by One-Way ANOVA, followed by Tukey's test and Significance at * $p<0.001$ compared with control.

\section{Abbreviations}

AChE: Acetylcholinesterase; ANOVA: Analysis of variance; CPD: Critical point drying; DDT: Dichlorodiphenyl trichloroethane; DNSA: 3,5-Dinitrosalicylic acid; DTNB: 5,5'-Dithiobis, 2-nitrobenzoic acid; EO: Essential oil; FESEM: Field emission scanning electron microscopy; GABA: Gamma amino butyric acid; GC-MS/MS: Gas chromatography-mass spectrometry/mass spectrometry; HMDS: Hexamethylenedisilazane; LC: Lethal concentration; LD: Lethal dose; $\mathrm{NaOH}$ : Sodium hydroxide; NCL: National chemical laboratory;

PBS: Phosphate-buffered saline; PIR: Percent inhibition rate; $\mathrm{RH}$ : Relative humidity; SEM: Scanning electron microscope; SEM: Standard error means; USFDA: United States Food and Drug Administration

\section{Acknowledgements}

$\mathrm{JC}$ is highly indebted to the authorities of the S.P. Pune University, Pune, India, for providing the research stipend. MD is grateful to the University Grants Commission (UGC), New Delhi, India, for senior research fellowship under the Maulana Azad National fellowship scheme. RSP acknowledges the UPE-II (nanobiotechnology), UoP-BCUD grant (15-SCI-001422), and DRDP and DST-PURSE schemes provided to the laboratory.

\section{Authors' contributions}

JC and RSP conceived and designed the experiments. JC and MD performed the experiments. JC, MD, and RSP wrote the paper. All authors read and approved the final manuscript.

\section{Funding}

The work was supported by Savitribai Phule Pune University, Pune, under the project code UoP-BCUD grant (15-SCI-001422), as well as DRDP and DST-PURSE schemes provided to the RSP.

Availability of data and materials

All the data generated from this study is included in the paper and can be accessed from the corresponding author upon request approval.

Ethics approval and consent to participate

Not applicable.

\section{Consent for publication}

Not applicable.

\section{Competing interests}

The authors declare that they have no competing interests.

Received: 12 June 2019 Accepted: 13 January 2020

Published online: 11 February 2020

\section{References}

Andronikashvili, M., \& Reichmuth, C. H. (2002). Repellency and toxicity of essential oils from Ocimum gratissimum (Lamiaceae) and Laurus nobilis (Lauraceae) from Georgia against the rust-red flour beetle Tribolium castaneum (Coleoptera: Tenebrionidae). In P. F. Credland, D. M. Armitage, C. H. Bell, P. M. Cogan, \& E. Highley (Eds.), Advances in stored products protection, proceedings York, UK, (pp. 749-762). Wallingford, Oxon: CAB International.

Asid, A. N., Al-Ghamdi, K. M., Nassar, M. I., \& Mangoud, A. (2015). Assessment of bitter apple, Citrullus colocynthis extracts on the housefly, Musca domestica L. Advances in Environmental Biology, 9(8), 72-78.

Azevedo, T. M., Terra, W. R., \& Ferreira, C. (2003). Purification and characterization of three $\beta$-glycosidases from midgut of the sugar cane borer, Diathraea saccharalis. Insect Biochemistry and Molecular Biology, 33, 81-92 https://doi. org/10.1016/S0965-1748(02)00179-0.

Bigham, M., Hosseininaveh, V., Nabavi, B., Talebi, K., \& Esmaeilzadeh, N. (2010). Effects of essential oil from Teucrium polium on some digestive enzyme activities of Musca domestica. Entomological Research., 40, 37-45 https://doi. org/10.1111/j.1748-5967.2009.00260.x.

Bradford, M. M. (1976). A rapid and sensitive method for the quantitation of microgram quantities of protein utilizing the principle of protein-dye 
binding. Analytical Biochemistry, 72, 248-254 https://doi.org/10.1016/00032697(76)90527-3.

Brattsten, L. B., Samuelian, J. H., Long, K. Y., Kincaid, S. A., \& Evans, C. K. (1983). Cyanide as a feeding stimulant for the southern armyworm, Spodoptera eridania. Ecological Entomology, 8, 125-132 https://doi.org/10.1111/j.13652311.1983.tb00490.x

Buescher, M. D., Rutledge, L. C., Wirtz, R. A., Blackin, K. B., \& Moussa, M. A. (1982). Laboratory tests of repellents against Lutzomyialongipalpis (Diptera: Psychodidae). Journal of Medical Entomology, 19, 176-180 PMID: 7086853.

Busvine, J. R. (1971). A critical review of the techniques for testing insecticides, (2nd ed., p. 345). London: Skough: Commonwealth Agricultural Bureau International Buereux.

Campbell, M. M. (1983). A test for repellency to non-biting flies and a comparison of repellents using Musca domestica L. Journal of Pesticides Science, 14, 199212 https://doi.org/10.1002/ps.2780140215.

Coats, J. R., Karr, L. L., \& Drewes, C. D. (1991). Toxicity and neurotoxic effects of monoterpenoids in insects and earthworms. In P. A. Hedin (Ed.), Naturally occurring pest bioregulators, (vol. 449, pp. 305-316) https://doi.org/10.1021/ bk-1991-0449.ch020.

Cosimi, S., Rossi, E., Cioni, P. L., \& Canale, A. (2009). Bioactivity and qualitative analysis of some essential oils from Mediterranean plants against storedproduct pests: Evaluation of repellency against Sitophilus zeamais Motschulsky, Cryptolestes ferrugineus (Stephens) and Tenebrio molitor (L.). Journal of Stored Products Research, 45, 125-132 https://doi.org/10.1016/j.jspr.2008.10.002.

Curtis, C. F., Lines, J. D., Baolin, L., \& Renz, A. (1990). Natural and synthetic repellents. In C. F. Curtis (Ed.), Appropriate technology in vector control, (pp. 75-92). Florida: CRC Press.

Drapeau, J., Frohler, C., Touraud, D., Krockel, U., Geier, M., Rose, A., \& Kunz, W. (2009). Repellent studies with Aedes aegypti mosquitoes and human of olfactory tests on 19 essential oils from Corsica. Flavour and Fragrance Journal, 24, 160-169 https://doi.org/10.1002/ff.1928.

Ellman, G. L., Courtney, K. D., Andres, V., \& Featherstone, R. M. (1961). A new and rapid colorimetric determination of acetylcholinesterase activity. Biochemical Pharmacology, 7, 88-95.

El-Zayyat, A. E., Soliman, M. I., Elleboudy, N. A., \& Ofaa, S. E. (2017). Bioefficacy of some Egyptian aromatic plants on Culex pipiens (Diptera: Culicidae) adults and larvae. Journal of Arthropod-Borne Diseases, 11, 147-155 PMID: 29026862.

Erler, F., Ulug, I., \& Yalcinkaya, B. (2006). Repellent activity of five essential oils against Culex pipiens. Fitoterapia, 77, 491-494 https://doi.org/10.1016/j.fitote. 2006.05.028.

Evrendilek, G. A. (2015). Empirical prediction and validation of antibacterial inhibitory effects of various plant essential oils on common pathogenic bacteria. International Journal of Food Microbiology, 202, 35-41 https://doi. org/10.1016/j.ijfoodmicro.2015.02.030.

Ferreira, C., \& Terra, W. R. (1989). Spatial organization of digestion, secretary mechanism and digestive enzyme properties in Pheropsophus aequinoctialis (Coleoptera: Carabidae). Insect Biochemistry., 19, 383-391 https://doi.org/10. 1016/0020-1790(89)90043-7.

Finney, D. (1952). Probit analysis: A statistical treatment of the sigmoid response curve, (p. 256). Cambridge University Press.

Fotedar, R., Banerjee, U., Singh, S., Shriniwas, \& Verma, A. K. (1992). The housefly (Musca domestica) as a carrier of pathogenic microorganism in a hospital environment. Journal of Hospital Infection, 20, 209-215 https://doi.org/10. 1016/0195-6701(92)90089-5.

Greenberg, B. (1973). Flies and disease. II. Biology and disease transmission, (vol. 15, p. 447). Princeton: Princeton University Press.

Grundy, D. L., \& Still, C. C. (1985). Inhibition of acetylcholinesterases by pulegone1, 2-epoxide. Pestic, Biochem. Physiol., 23, 383-388 https://doi.org/10.1016/ 0048-3575(85)90100-2.

Gumus, T., Demirci, A. S., Sagdic, O., \& Arici, M. (2010). Inhibition of heat resistant molds: Aspergillus fumigates and Paecilomyces variotti by some plant essential oils. Food Science and Biotechnology, 19, 1241-1244 https://doi.org/10.1007/ s10068-010-0177-9.

Gustafson, J. E., Liew, Y. C., Chew, S., Markham, J. L., Bell, H. C., Wyllie, S. G., et al. (1998). Effects of tea tree oil Escherichia coli. Letters in Applied Microbiology., 26, 194-198 https://doi.org/10.1046/j.1472-765X.1998.00317.x.

Hichri, F., Omri, A., Hossan, A. S. M., \& Jannet, H. B. (2019). Alpha-glucosidase and amylase inhibitory effects of Eruca vesicaria subsp. longirostris essential oils: Synthesis of new 1,2,4-triazole-thiol derivatives and 1,3,4-thiadiazole with potential inhibitory activity. Pharmaceutical Biology, 57, 564-570 https://dx. doi.org/10.1080\%2F13880209.2019.1642363.
Huang, Y., Ho, H., Lee, H., \& Yap, H. (2002). Insecticidal properties of eugenol, isoeugenol and methyleugenol and their effects on nutrition of Sitophilus zeamais Motsch. (Coleoptera: Curculionidae) and Tribolium castaneum (Coleoptera: Tenebrionidae). Journal of Stored Product Research, 38, 403-412 https://doi.org/10.1016/50022-474X(01)00042-X.

Inan, O., Ozcan, M. M., \& Juhaimi, F. Y. A. (2012). Anti-oxidant effect of mint, laurel and myrtle leaves essential oils on pomegranate kernel, poppy, grape and linseed oils. Journal of Cleaner Production, 27, 151-154 https://doi.org/10. 1016/j.jclepro.2012.01.003.

Insun, D., Choochote, W., Jitpakdi, A., Chaithong, U., Tippawangkosol, P., \& Pitasawat, B. (1999). Possible site of action of Kaempferia galanga in killing Culex quinquefasciatus larvae. Southeast Asian Journal of Tropical Medicine and Public Health, 30, 195-199 PMID: 10695810.

Jongsma, M. A., \& Bolter, C. (1997). The adaptation of insects to plant protease inhibitors. Journal of Insect Physiology, 43, 885-895 https://doi.org/10.1016/ S0022-1910(97)00040-1.

Khan, H., Akram, W., Shad, S. A., Razaq, M., Naeem-Ullah, U., \& Zia, K. (2013). A cross sectional survey of knowledge, attitude and practices related to house flies among dairy farmers in Punjab, Pakistan. Journal of Ethnobiology and Ethnomedicine, 9, 18 https://dx.doi.org/10.1186\%2F1746-4269-9-18.

Khater, H. F. (2012). Prospects of botanical biopesticides in insect pest management. Pharmacologia., 3, 641-656 https://doi.org/10.5567/ pharmacologia.2012.641.656.

Kobayashi, M., Sasaki, T., Saito, N., Tamura, K., Suzuki, K., Watanabe, H., \& Agui, N. (1999). Houseflies: Not simple mechanical vectors of entero-hemorrhagic, Escherichia coli 0157:H7. American Journal of Tropical Medicine and Hygiene, 61, 625-629 PMID: 10548298.

Koul, O. (2008). Phytochemicals and insect control: An antifeedant approach. Critical reviews in plant sciences., 27, 1-24 https://doi.org/10.1080/ 07352680802053908.

Kumar, P., Mishra, S., Malik, A., \& Satya, S. (2011). Repellent, larvicidal and pupicidal properties of essential oils and their formulations against the housefly, Musca domestica. Medical and Veterinary Entomology, 25, 302-310 https://doi.org/10. 1111/j.1365-2915.2011.00945.x.

Lee, S., Peterson, C. J., \& Coats, J. R. (2003). Fumigation toxicity of monoterpenoids to several stored product insects. Journal of Stored Products Research, 39, 77-85 https://doi.org/10.1016/S0022-474X(02)00020-6.

Lorenzi, H., \& Matos, F. J. A. (2008). Plantas medicinais no Brasilnativas e exoticas, (2nd ed., ). Sao Paulo: Instituto Plantarum.

Nakonieczny, M., Michalczyk, K., \& Kedziorski, A. (2006). Midgut glycosidases activities in monophagous larvae of Apollo butterfly, Parnassius apollos sp. frankenbergeri. CR Biology, 329, 765-774 https://doi.org/10.1016/..crvi.2006.06.009.

Nathan, S. S., Chung, P. G., \& Murugan, K. (2005). Effect of biopesticides applied separately or together on nutritional indices of the rice leaffolder Cnaphalocrocis medinalis. Phytoparasitica., 33, 187-195 https://doi.org/10.1007/BF03029978.

Nayak, S., Nalabothu, P., Sandiford, S., Bhogadi, V., \& Adogwa, A. (2006). Evaluation of wound healing activity of Allamanda cathartica. L. and Laurus nobilis. L. extracts on rats. BMC Complementary and Alternative Medicine, 6, 12 https:// doi.org/10.1186/1472-6882-6-12.

Nehir, S. E., Karagozlu, N., Karakaya, S., \& Sahin, S. (2014). Antioxidant and antimicrobial activities of essential oils extracted from Laurus nobilis L. leaves by using solvent free microwave and hydro distillation. Food and Nutrition Sciences., 5, 97-106 https://doi.org/10.4236/fns.2014.52013.

Oussalah, M., Caillet, S., Salmieri, S., Saucier, L., \& Lacroix, M. (2007). Antimicrobial effects of alginate-based films containing essential oils on Listeria monocytogenes and Salmonella typhimurium present in bologna and ham. Journal of Food Protection, 70, 901-908 https://doi.org/10.4315/0362-028X-70.4.901.

Palacios, S. A., Bertoni, A., Rossi, Y., Santander, R., \& Urzua, A. (2009). Efficacy of essential oils from native medicinal plants of central Argentina against the house fly, Musca domestica L. Molecules., 14, 1938-1947 https://doi.org/10. 1007/s00436-009-1651-2.

Palacios, S. A., Bertoni, A., Rossi, Y., Santander, R., \& Urzua, A. (2009b). Efficacy of essential oils from edible plants as insecticides against the house fly, Musca domestica $\mathrm{L}$. Molecules., 14, 1938-1947 https://doi.org/10.3390/molecules14051938.

Papachristos, D. P., \& Stamopoulos, D. C. (2002). Repellent, toxic and reproduction inhibitory effect of essential oil vapours on Acanthoscelides obtectus (Say) (Coleoptera: Bruchidae) J. Journal of Stored Products Research, 38, 117-128 https://doi.org/10.1016/S0022-474X(01)00007-8.

Pavela, R. (2008). Insecticidal properties of several essential oils on the house fly (Musca domestica L.). Phytotherapy Research., 22, 274-278 https://doi.org/10. 1002/ptr.2300. 
Peris, I., \& Blázquez, M. A. (2015). Comparative GC-MS analysis of bay leaf (Laurus nobilis L.) essential oils in commercial samples. International Journal of Food Properties, 18, 757-762 https://doi.org/10.1080/10942912.2014.906451.

Plummer (1988). An introduction to practical biochemistry, (3rd ed., ). New Delhi: Tata McGraw-Hill Publi.Com. Ltd.

Rajashekar, Y., Raghavendra, A., \& Bakthavatsalam, N. (2014). Acetylcholinesterase inhibition by biofumigant (Coumaran) from leaves of Lantana camarain in stored grain and household insect pests. BioMed Research International, 187019, 6 https://doi.org/10.1155/2014/187019.

Regnault-Roger, C. (1997). The potential of botanical essential oils for insect pest control. Integrated Pest Management Reviews, 2, 25-34 https://doi.org/10. 1023/A:1018472227889.

Rozman, V., Kalinovic, I., \& Korunic, Z. (2007). Toxicity of naturally occurring compounds of Lamiaceae and Lauraceae to three stored-product insects. Journal of Stored Products Research, 43, 349-355 https://doi.org/10.1016/j.jspr. 2006.09.001.

Rutledge, L. C., Collister, D. M., Meixsell, V. E., \& Eisenberg, G. H. G. (1983). Comparative sensitivity of representative mosquitoes (Diptera: Culicidae) to repellents. Journal of Medical Entomology, 20, 506-510 https://doi.org/10. 1093/jmedent/20.5.506.

Ryan, M. F., \& Byrne, O. (1988). Plant insect co evolution and inhibition of acetylcholinesterase. Journal of Chemical Ecology, 14, 1965-1975 https://doi. org/10.1007/BF01013489.

Sayyah, M., Saroukhani, G., Peirovi, A., \& Kamalinejad, M. (2003). Analgesic and anti-inflammatory activity of the leaf essential oil of Laurus nobilis Linn. Phytotherapy Research, 17, 733-736 https://doi.org/10.1002/ptr.1197.

Senfi, F., Safaralizadeh, M. H., \& Safaris, S. A. (2014). Aramideh, fumigant toxicity of Laurus nobilis and Myrtus communis essential oils on larvae and adults of the red flour beetle, Tribolium castaneum Herbst (Col: Tenebrionidae). Archives of phytopathology and plant protection., 47, 472-476 https://doi.org/10.1080/ 03235408.2013.812819.

Senthilm, N. S., Choi, M. Y., Seo, H. Y., Paik, C. H., Kalaivani, K., \& Kim, J. D. (2008). Effect of azadirachtin on acetylcholinesterase (AChE) activity and histology of the brown planthopper Nilaparvata lugens (Stål). Ecotoxicology and Environmental Safety, 70, 244-250 https://doi.org/10.1016/j.ecoenv.2007.07. 005.

Sertkaya, E., Kaya, K., \& Soylu, S. (2010). Acaricidal activities of the essential oils from several medicinal plants against the carmine spider mite (Tetranychus cinnabarinus Boisd.) (Acarina: Tetranychidae). Industrial Crops and Products., 31 , 107-112 https://doi.org/10.1016/j.indcrop.2009.09.009.

Sezginturk, M. K., \& Dinckaya, E. (2008). $\beta$-galactosidase monitoring by a biosensor based on Clark electrode: Its optimization, characterization and application. Biosensors and Bioelectronics., 23, 1799-1804 https://doi.org/10.1016/j.bios. 2008.02.017.

Strobl, S., Maskos, K., Wiegand, G., Huber, R., Gomis-Ruth, F., \& Glockshuber, R. (1998). A novel strategy for inhibition of a-amylases: yellow meal worm aamylase in complex with Ragi bifunctional inhibitor at $2.5 \AA$ resolution. Structure., 6, 911-921 https://doi.org/10.1016/S0969-2126(98)00092-6.

Sukontason, K. L., Boonchu, N., Sukontason, K., \& Choochote, W. (2004). Effects of eucalyptol on house fly (Diptera: Muscidae) and blow fly (Diptera: Calliphoridae). Revista do Instituto de Medicina Tropical de São Paulo, 46, 97101 https://doi.org/10.1590/S0036-46652004000200008.

Tabashnik, B. E., \& Johnson, M. W. (1999). Evolution of pesticide resistance in natural enemies. In T. S. Belows, \& T. W. Fisher (Eds.), Handbook of biological control: principles and applications of biological control, (vol. 23, pp. 673-689). Academic press. Elsevier https://doi.org/10.1016/B978-012257305-7/50071-0.

Terra, W. R., Espinoza-Fuentes, F. P., Ribeiro, A. F., \& Ferreira, C. (1988). The larval midgut of the housefly (Musca domestica): Ultrastructure, fluid fluxes and ion secretion in relation to the organization of digestion. Journal of Insect Physiology., 34, 463-472 https://doi.org/10.1016/0022-1910(88)90187-4.

Ultee, A., Kets, E. P., Alberda, M., Hoekstra, F. A., \& Smid, E. J. (2000). Adaptation of the food-borne pathogen Bacillus cereus to corvacrol. Archives of Microbiology, 174, 233-238 PMID: 11081791.

Van Handel, E., \& Day, J. F. (1988). Assay of lipids, glycogen and sugars in individual mosquitoes: correlations with wing length in field-collected Aedes vexans. Journal of the American Mosquito Control Association, 4, 549-550 PMID: 3225576

Wanaratana, S., Amonsin, A., Chaisingh, A., Panyim, S., Sasipreeyajan, J., \& Pakpinyo, S. (2013). Experimental assessment of houseflies as vectors in avian influenza subtype H5N1 transmission in chickens. Avian Diseases, 57, 266-272 https://doi.org/10.1637/10347-090412-Reg.1.
Wang, Z., Zhao, Z., Cheng, X., Liu, S., Wei, Q., \& Scott, I. M. (2016). Conifer flavonoid compounds inhibit detoxification enzymes and synergize insecticides. Pesticide Biochemistry and Physiology, 127, 1-7 https://doi.org/10. 1016/j.pestbp.2015.09.003.

\section{Publisher's Note}

Springer Nature remains neutral with regard to jurisdictional claims in published maps and institutional affiliations.

\section{Submit your manuscript to a SpringerOpen ${ }^{\circ}$ journal and benefit from:}

- Convenient online submission

- Rigorous peer review

- Open access: articles freely available online

- High visibility within the field

- Retaining the copyright to your article

Submit your next manuscript at $\boldsymbol{\nabla}$ springeropen.com 